\title{
The Difference of Compliance Cost Before and After Using E-Filing Application on Company Taxpayers E-Filing User
}

\author{
Vania Wimayo \\ Universitas Airlangga \\ vaniawimayo92@gmail.com
}

\begin{abstract}
The purpose of this study was to determine differences in compliance cost incurred before and after the use of E-Filing applications for corporate tax payers E-Filing users.E-Filing Tax Return is a reporting system created by the DGT which makes it easy for taxpayers in the manufacture and delivery of Tax Return report to the Director General of Taxation. The hypothesis in this study was tested using the Wilcoxon test match pairs. The type of data used in this study is quantitative data. The research method used is a survey and the instrument used to collect data is a questionnaire. The results show that compliance cost after the use of e-filing in contrast to earlier, where the compliance cost will be lower.
\end{abstract}

Keywords: e-filling, compliance cost, tax payers

\begin{abstract}
Abstrak
Tujuan dari penelitian ini untuk mengetahui perbedaan compliance cost yang dikeluarkan sebelum dan sesudah penggunaan aplikasi E-Filing bagi wajib pajak badan pengguna E-Filing. E-Filing adalah sistem pelaporan SPT yang dibuat oleh Dirjen Pajak yang memberikan kemudahan bagi wajib pajak dalam pembuatan dan penyerahan laporan SPT kepada Dirjen Pajak. Hipotesis dalam penelitian ini di diuji menggunakan Wilcoxon match pairs test. Tipe data yang digunakan dalam penelitian ini adalah data kuantitatif. Metode penelitian yang digunakan adalah survei dan dan instrument yang dipakai untuk mengumpulkan data adalah kuesionair. Hasilnya menunjukkan bahwa compliance cost sesudah penggunaan e-filing berbeda dengan sebelumnya, dimana compliance cost menjadi lebih rendah.
\end{abstract}

Kata Kunci: e-filling, biaya kepatuhan, wajib pajak 


\section{INTRODUCTION}

The taxation system in Indonesia adheres to the Self Assessment system. The taxpayer was given the authority to calculate, pay and report their own taxes. The system encourages taxpayers to transparency and responsibility for the calculation of tax. On the otherhand the tax authorities should also monitor compliance of taxpayers. Monitoring taxes low and middle financial development contributes to small businesses and small medium large enough where the response to the tax transparency is important. (Pappadá and Zylberberg, 2017)

With more advanced economic life of today's society it is increasingly also public obligation to pay taxes. Society today want the service that is fast, easy, cheap and quality. That is also the public wanted the tax service.

Given the demands of the community will be the quality and effective service, the Directorate General of Taxation trying to modernize the system of taxation services

With the aim of modernization as mentioned above, the Director General of Taxation is required to make the program - a new program that could improve taxpayer compliance and confidence to the DGT. The findings show that the quality of tax services are important determinants for the use of online tax system that gives relevance to the tax administration system. (Mustaphaa et.al, 2014)

One program that is currently a hot topic is the e-Filing. In a previous study explained that electronic filing (E-Filing) is an important application that automates the process related taxes in an effort to improve efficiency in assessing and collecting tax information. It has the potential to improve tax filing services while at the same time reduce costs for taxpayers and tax collectors agent (Fu et.al, 2006). E-Filing is a way of delivering the annual tax return electronically conducted online and in real time via the internet on the website of the Directorate General of Taxes (www.pajak.go.id). Via e-Filing, taxpayers may submit tax returns from anywhere as long as can access www.pajak.go.id and within 24 hours a day, 7 days a week

Acceptance of e-filing by the public are significantly influenced by their confidence in e-filing providers they use to complete and submit their tax returns online. Trust e-file provider has been shown to reduce the perceived risk of citizens and increase the likelihood of their use. It highlights, for both government agencies and e-filing service providers actually, the fact that a relationship of trust with the citizens during the e-filing process is very important and must be nurtured relationships built. (Schaupp et.al, 2010)

E-filing also have potential for cost savings on the public sector side of the taxation system, reducing the cost of tax administration. In particular, the computerization of all tax records can reduce errors and reduce the tax authorities efforts in sorting and analyzing the tax files, in addition to the potential for the reduction of corruption and informal interaction between taxpayers and tax officials. (Yilmaz and Coolidge, 2013). Determine behavioral expectations of government support. Thus, the government should support the end user with a guide for instructions and provide 24/7 technical support services to help them when filling out their taxes online or when the system is breaking down. The 
government must implement a proactive strategy to inform citizens about the benefits of income tax filings through the online channel. (Carter et al, 2011)

However, it turns out taxpayers using e-Filing is practically very low. This is evidenced by previous study explains that although the tax reporting electronically increasingly popular among taxpayers, but most people use this system to get the experience to submit taxes electronically with the ability to navigate the bad and the taste was not sure about the functionality, security, and concern over their sensitive information, which can cause users to give up. (Santhanamery, 2012)

In 2017 taxpayers in Indonesia that utilizes a new e-Filing 6931 totaled taxpayer. Whereas almost all Indonesian citizens are familiar with the Internet-based system.

This is certainly interesting researched why e-Filing has not been popular among the people, especially the taxpayers. In fact, e-Filing is expected to reduce costs - costs taxpayers to meet their tax obligations (cost of compliance).

Based on previous research (Vaillancourt, 2008) Vaillancourt observed that the level of compliance costs incurred for fiscal years 2004 and 2005 was lower at 1.7 percent compared to compliance costs in 1987 where e-filing had not been used, namely 3 percent.

Another study conducted by Klun $(2004,2009)$ has examined the effects of tax reform, one of which is efiling use, the results of the study show that the trend of decreasing compliance costs during tax reform or when e-filling begins to be used. But based on research (Evan, 2008; Ibrahim, 2014) the effect of using e-filling does not affect the compliance cost of taxpayers. From the previous research, there are differences in interesting research results to be examined in Indonesia with different taxation systems.

The novelty of the research conducted is that this research was carried out in the taxation system in Indonesia. Researchers want to re-examine existing research because based on previous research studies carried out in developed countries that have different taxation systems

To simplify the existing discussion, the writing is divided into the first introduction, hypothesis formation, afterwards discussing research methodology, and the last is the result of research and Conclusions and Policy Implication.

The hypothesis of this study are: H0: Compliance costs prior to the use of e-filing compliance cost the same as after the use of e-filing. H1: Compliance costs prior to the use of e-filing is not the same as the compliance cost after the use of e-filing.

\section{METHODS}

Referring to the relationship - a relationship which is illustrated through the hypotheses that have been developed previously, can be obtained an analytical model. The analytical model is derived from the relationship - the relationship between variables, namely the e-filing system and compliance cost. This study will test compliance cost difference before and after the use of e-filing. Model analysis can be described as follows: 
Table 1. Model analysis

\begin{tabular}{ll}
\hline Before Compliance costs & After compliance cost \\
\hline 1. Direct costs money & 1. Direct costs money \\
2. Time costs & 2. time costs \\
\hline
\end{tabular}

In this study will be examined as to whether there are differences in compliance cost before and after the use of e-filing. Therefore, it should be known indicators of compliance cost itself, so that later can be seen whether there are differences in compliance cost before and after the use of e-filing.

Table 2. Indicator compliance cost

\begin{tabular}{l} 
Indicator \\
\hline Direct costs money : Personnel costs of tax, the cost of tax consultants, the cost of the seminar / training \\
taxation, the cost of buying the software taxation, the cost of telephone and internet, photocopying, printing, \\
fax, stationery to make a tax return, the cost to provide a place to file taxes, transportation costs, fees for \\
tax training for employees \\
time costs : Time to go to the LTO, the time for tax management, time queuing at the LTO, the time to \\
fulfill tax return, the time to read the manual filling tax return, the time to learn the rules of taxation \\
applicable, the time to take care of the tax administration.
\end{tabular}

The scale of measurement used in this study is an ordinal scale. Ordinal scale is a scale that gives the sense of priority or ranking, in which a given code provides a specific sequence in the data, but does not show the same differences and no absolute zero. Ordinal scale typically using non-parametric statistical analysis.

In this study also used a questionnaire to measure the attitudes and opinions regarding whether there is a change in the compliance cost before and after the use of e-filing. The scale is used, as described earlier is an ordinal scale. the measurement with a choice of four answers, which is "Strongly Agree" (SS), "Agree" (S), "Disagree" (TS), "Strongly Disagree" (STS). For each of these answers were weighted value of: "Strongly Agree $(\mathrm{SS})=4$, "Agree" $(\mathrm{S})=3$, "Disagree" (TS), = 2, "Strongly Disagree" (STS)=1

Data used in this research is quantitative data is the data that can be measured using a digit. Quantitative methods, according to Jane Stokes in his book How To Do Media And Cultural Studies (2003), translated into Indonesian, is a method based on numerical information or quantity and is usually associated with statistical analysis.

Source of data used Primary data, that is data obtained directly from the object, without any intermediary. In this study, primary data obtained from questionnaires.

In this study using survey research methods, so that the instrument or tool used to collect data was questionnaire. The data collection is done by distributing a list of structured questions in the questionnaire to the respondent, ie corporate taxpayers who use e-filing application After the questionnaires filled out by the respondents, it will be returned to the spreader questionnaire. 
In this study were sampled corporate taxpayers who use e-filing. The sampling technique used is random sampling, where sampling was conducted randomly, regardless of the strata. While the sampling method used was simple random sampling where every member of the population have an equal opportunity to be selected, regardless of the existing strata, and every member of the population only get one chance to be selected.

In this study, measuring instruments used were questionnaires. The questionnaire considered valid if the question on the questionnaire were able to reveal something that will be measured. To test the validity, then use the formula:

$$
r=\frac{n \sum X Y-\sum X \sum Y}{\sqrt{\left(\left(n \sum X^{2}-\left(\sum X\right)^{2}\right)\left(n \sum Y^{2}-\left(\sum Y\right)^{2}\right)\right)}}
$$

Where:

$r=$ coefficient of correlation Pearson Product Moment

$\mathrm{n}=$ Number of respondents who used

$\mathrm{x}=$ Score each item

$\mathrm{y}=$ total score of respondents on the whole question

Reliability test is used to determine the consistency of a measuring instrument, namely whether the instruments had results with the level of stability and high accuracy over time. To measure the reliability we used Cronbach alpha formula, namely:

$$
\boldsymbol{\alpha}=\frac{k}{k-1}\left(1-\frac{\sum S^{2} j}{S^{2} x}\right)
$$

Where:

$\alpha=$ Cronbach alpha reliability coefficient

$\mathrm{k}=$ number of items

$\mathrm{Sj}$ = variance of respondents to score items

$\mathrm{Sx}=$ the amount of variance of total score

Reliability is also divided into several levels, namely: alpha $>0.90$ then perfect reliability, alpha between 0.70 to 0.90 the high reliability, alpha between 0.50 to 0.70 then moderate reliability, alpha $<0.50$ then the low reliability. Hypothesis test used was Wilcoxon Match pairs test, which is to test the hypothesis of comparative two samples relating to data in the form ordinal.

Phase-phase commit Wilcoxon test: 1) Determining the formulation of a hypothesis (H1 and H0), 2) Determining the level of significance ( $\alpha=0.05)$ to determine the T table. 3 ) Counting T count: Determining the different sign and magnitude of the difference between pairs of data pins, Sorting difference regardless of the sign or hierarchy, Separating the different signs that the positive and negative, Add up all the numbers of positive and negative numbers, Determining the value of $\mathrm{T}$ is calculated by selecting the smallest absolute value of T. 4) Concluded by comparing the value of the $\mathrm{T}$ table with the value 
of $\mathrm{T}$ is calculated, if: Value $\mathrm{T}$ arithmetic $>\mathrm{T}$ table, then $\mathrm{H} 0$ is accepted, Value $\mathrm{T}$ count $<$ or $=\mathrm{T}$ table, then $\mathrm{H} 1$ accepted. 5) Conclusions: When $\mathrm{Z}$ count $>$ or $=\mathrm{Z}$ table, then the difference $n_{1}$ and $n_{2}$ are significant, When $\mathrm{Z}$ count $<\mathrm{Z}$ table, then the difference $\mathrm{n}_{1}$ and $\mathrm{n}_{2}$ difference is not significant. In order facilitate this Wilcoxon test, then it will be used SPSS 19.0. 6) To test the significance of the formula:

$$
z=\frac{T-\frac{1}{4} n(n+1)}{\sqrt{\frac{1}{24} n(n+1)(2 n+1)}}
$$

Where:

$\mathrm{n}=$ lots of data that changes after being given different treatment

$\mathrm{T}=$ number ranking of the value of the difference is negative

\section{RESULT AND DISCUSSION}

In doing some research to find out whether there are differences in compliance cost before and after the use of e-filing on the agency shall use the questionnaire distributed to the users of e-filing. Has obtained 50 respondents who will fill out the questionnaire sent by post.

The research instrument used was a questionnaire. To measure whether there are differences in compliance cost seblum and after the use of e-filing then compiled 18 questions regarding compliance cost before and after the use of e-filing.

So, should test the validity and reliability for testing whether the measuring instrument, the questionnaire is feasible, reliable and consistent. Test the validity of using the formula Pearson product moment correlation and reliability test using Cronbach alpha formula. Calculation of the validity and reliability test will be assisted by using SPSS version 19 .

Calculation of test validity and reliability to the question of compliance cost is:

- Before the use of e-filing:

Table 4. Item-Total Statistics

\begin{tabular}{ccccc}
\hline number & $\begin{array}{c}\text { Scale Mean if } \\
\text { Item Deleted }\end{array}$ & $\begin{array}{c}\text { Scale Variance if } \\
\text { Item Deleted }\end{array}$ & $\begin{array}{c}\text { Corrected Item-Total } \\
\text { Correlation }\end{array}$ & $\begin{array}{c}\text { Cronbach's Alpha if } \\
\text { Item Deleted }\end{array}$ \\
\hline no. 1 & 58.9400 & 19.364 &, 434 &, 818 \\
no. 2 & 58.6200 & 20.404 &, 111 &, 836 \\
no. 3 & 58.5400 & 19.437 &, 361 &, 822 \\
no. 4 & 58.7200 & 19.634 &, 266 &, 828 \\
no. 5 & 58.6400 & 19.419 &, 349 &, 822 \\
no. 6 & 58.4000 & 19.469 &, 356 &, 822 \\
no. 7 & 58.4200 & 19.840 &, 267 &, 827 \\
\hline
\end{tabular}




\begin{tabular}{ccccc}
\hline number & $\begin{array}{c}\text { Scale Mean if } \\
\text { Item Deleted }\end{array}$ & $\begin{array}{c}\text { Scale Variance if } \\
\text { Item Deleted }\end{array}$ & $\begin{array}{c}\text { Corrected Item-Total } \\
\text { Correlation }\end{array}$ & $\begin{array}{c}\text { Cronbach's Alpha if } \\
\text { Item Deleted }\end{array}$ \\
\hline no. 8 & 58.4800 & 18.867 &, 493 &, 815 \\
no.9 & 58.4200 & 18.575 &, 569 & 811 \\
no.10 & 58.4800 & 19.316 &, 386 &, 820 \\
no.11 & 58.5600 & 18.823 &, 512 &, 814 \\
no.12 & 58.5800 & 19.024 &, 467 &, 816 \\
no.13 & 58.4000 & 19.020 &, 464 &, 815 \\
no.14 & 58.4800 & 18.908 &, 483 &, 813 \\
no.15 & 58.7000 & 18.582 &, 523 & 811 \\
no.16 & 58.4200 & 18.616 &, 559 &, 814 \\
no.17 & 58.4800 & 18.785 &, 513 &, 439 \\
no.18 & 58.3800 & 19.138 & &, 818 \\
\hline
\end{tabular}

From the table 4 it can be seen if the results of the corrected item-total correlation is positive. Item questions considered valid if the result corrected item-total correlation nothing negative. So based on the results of the table all the questions are valid.

Table 5. Reliability Statistics

\begin{tabular}{cc}
\hline Cronbach's Alpha & N of Items \\
\hline, 827 & 18 \\
\hline
\end{tabular}

The output of the results table can be seen if the value of Cronbach's alpha was 0.827. The questionnaire is considered reliable if the alpha $r>r$ table. From $r$ tables can dipeoleh for $\mathrm{N}=50$ and $5 \%$ significance level is 0.279 . Because $0.827>0.279$ then the instrument is reliable.

The output of the results table can be seen if the value of Cronbach's alpha was 0.756. The questionnaire is considered reliable if the alpha $r>r$ table.

Table 6. Reliability Statistics

\begin{tabular}{cc}
\hline Cronbach's Alpha & N of Items \\
\hline, 756 & 18 \\
\hline
\end{tabular}

From $r$ tables can dipeoleh for $\mathrm{N}=50$ and $5 \%$ significance level is 0.279 . Because $0.756>0.279$ then the instrument is reliable. 
- After the use of e-filing

Table 7. Item-Total Statistics

\begin{tabular}{|c|c|c|c|c|}
\hline number & $\begin{array}{l}\text { Scale Mean if } \\
\text { Item Deleted }\end{array}$ & $\begin{array}{l}\text { Scale Variance if } \\
\text { Item Deleted }\end{array}$ & $\begin{array}{l}\text { Corrected Item } \\
\text { Total Correlation }\end{array}$ & $\begin{array}{l}\text { Cronbach's Alpha if } \\
\text { Item Deleted }\end{array}$ \\
\hline no. 1 & 43.4800 & 14.091 & 245 & ,753 \\
\hline no. 2 & 43.4600 & 14.253 & 202 & ,756 \\
\hline no. 3 & 43.4400 & 13.762 & 342 & 745 \\
\hline no. 4 & 43.5000 & 13.847 & ,310 & ,747 \\
\hline no. 5 & 43.4000 & 13.633 & 390 & 741 \\
\hline no. 6 & 43.5800 & 13.759 & ,335 & ,745 \\
\hline no. 7 & 43.6000 & 14.082 & 247 & ,753 \\
\hline no. 8 & 43.3000 & 13.071 & 623 & ,724 \\
\hline no. 9 & 43.3600 & 13.541 & 433 & ,738 \\
\hline no. 10 & 43.4800 & 13.520 & 405 & 740 \\
\hline no. 11 & 43.4400 & 13.680 & 366 & ,743 \\
\hline no. 12 & 43.5200 & 13.193 & 495 & 732 \\
\hline no. 13 & 43.6000 & 13.592 & ,384 & ,741 \\
\hline no. 14 & 43.4600 & 13.274 & 479 & ,733 \\
\hline no. 15 & 43.7000 & 14.990 & 012 & ,770 \\
\hline no. 16 & 43.5200 & 14.459 & 143 & 761 \\
\hline no. 17 & 43.5000 & 14.704 & ,079 & ,766 \\
\hline no. 18 & 43.3400 & 13.127 & 573 & 727 \\
\hline
\end{tabular}

From table 7 it can be seen if the results of the corrected item-total correlation is positive. Item questions considered valid if the result corrected item-total correlation nothing negative. So based on the results of the table all the questions are valid.

Table 8. Test Statistics

\begin{tabular}{cc}
\hline & After before \\
\hline $\mathrm{Z}$ & $-6,159 \mathrm{a}$ \\
Asymp. Sig. (2-tailed) &, 000 \\
\hline a. Based on positive ranks., b. Wilcoxon Signed Ranks Test
\end{tabular}

In the table of test statistics obtained $\mathrm{Z}$ count $=-6.159 . \mathrm{Z}$ table with a significance level of $95 \%$ and a two-sided test obtained value of 1.96 
Test Wilcoxonis used to determine whether there are differences in compliance cost before and after the use of e-filing. The results obtained from the Wilcoxon test through SPSS version 19 is:

Table 9. Wilcoxon test results (Rank)

\begin{tabular}{ccccc}
\hline & $\mathbf{N}$ & Mean Rank & Sum of Ranks \\
\hline After before & negative Ranks & $50 \mathrm{a}$ & 25,50 & 1275.00 \\
\cline { 2 - 5 } & positive Ranks & $0 \mathrm{~b}$ &, 00 &, 00 \\
\cline { 2 - 4 } & Ties & $0 \mathrm{c}$ & & \\
\hline & Total & 50 & \\
\hline
\end{tabular}

a. After <Prev, b. After $>$ Before, c. After $=$ Before

From the results obtained, the table ranks, to negative ranks is 50 , positive ranks 0 , ties 0, which means scores / grades (compliance costs) after the use of e-filing is smaller than before the use of e-filing.

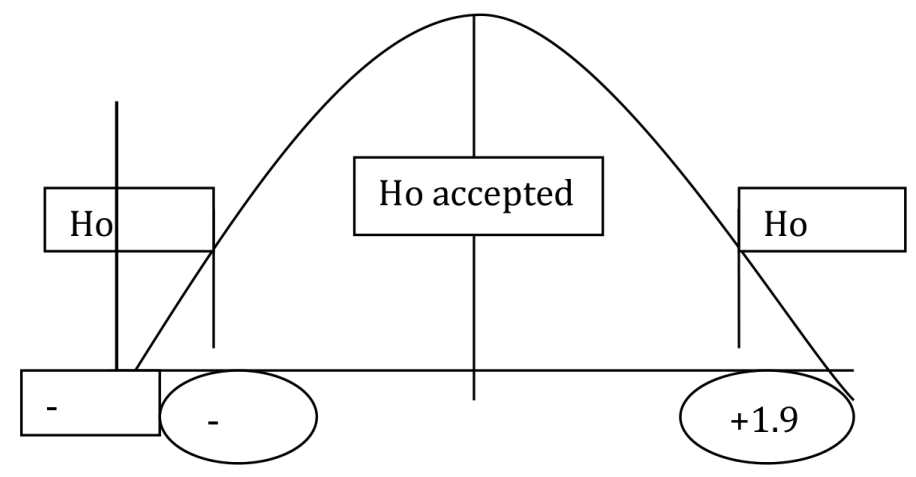

Because the count value $\mathrm{z}$ is located in the $\mathrm{HO}$ is rejected, then the decision is to reject $\mathrm{HO}$, which means compliance cost prior to the use of e-filing is not the same as the compliance cost after e-filing. Conditions probability figure: The probability of $>0.05$ then H0, The probability of $<0.05$ then $\mathrm{HO}$ is rejected.

Under these provisions, the Asymp.Sig value. (2-tailed) in the table is 0.00 , where 0.00 $<0.05$ then the result is the same, ie $\mathrm{H0}$ is rejected. So there are differences in compliance cost before and after the use of e-filing, which compliance cost becomes smaller.

From the results of hypothesis testing is done, it can be concluded that there are differences in compliance cost before and after the use of e-filing, which compliance cost after the use of e-filing becomes smaller.

This is certainly a bit different from previous research (Idawati Ibrahim, 2014; Klum, 2009) that lead to the conclusion that there were no significant differences in compliance cost after the use of e-filing.

Differences in results of this study with previous research that could be caused because there is a change in the e-filing procedure. The change them if previously taxpayers 
e-filing user charged registration fee now there are no registration fee. Also the taxpayer no longer need to report tax return parent and documents - documents related to the LTO, like the previous procedure, unless requested by the LTO.

From the results obtained, namely the compliance cost after the use of e-filing in contrast to earlier, where the compliance cost will be lower in line with research conducted by (Vaillancourt, 2008; club 2004, 2009), then this is in accordance with what is expected by the Directorate General of Taxation (DGT), which is that there are services for taxpayers who fast and quality and can keep costs as low as possible, both in terms of the taxpayer or of the DGT.

It can be seen from the main purpose of the use of e-filing, One of the main goals of e-filing is to help reduce the cost and time required by the taxpayer to prepare, process and report to the tax office tax return correctly and on time. Then look at the findings contained, the main goal has been reached.

\section{CONCLUSION}

From the research results can be concluded The use of e-filing applications positive impact on the reduction of compliance costs, which costs taxpayers using e-filing will be lower.Decreased compliance cost is also due to the simplification of procedures where taxpayers using e-filing is not being charged anymore and does not need to come to the LTO, unless there is data requested by the LTO. With positive results, in which the costs incurred by the taxpayer can be reduced, then the tax authorities succeed in achieving as expected, which is to provide quality service and fast for the taxpayer.

The study was limited only to the company taxpayer. For further research to investigate corporate taxpayers and individual taxpayers

Based on the results of research that shows a decrease in compliance cost of taxpayers, it is expected that the directorate general of taxes will always improve e-filling services provided so that taxpayers can optimally use e-filling services and do not need to use manual methods to carry out their tax obligations.

\section{REFERENCE}

Aziz, SA, and Idris, KM. (2014). Does design matter in tax e-filing acceptance?. International Conference on Accounting Studies. Kuala Lumpur: Elsevier Ltd. 451-457

Azmi, A., Sapiei, NS, and Mustapha, MZ (2016). SMEs' Tax Compliance Costs and IT Adoption: The Case of a Value Added Tax. International Journal of Accounting Information Systems. 1-13.

Bruner, DM, D'Attoma, J., \& Steinmo, S. (2017). The Role of Gender in the Provision of Public Goods Through Tax Compliance. Journal of Behavioral and Experimental Economics. 45-55.

Carter, L., Schaupp, LC, \& McBride, ME. (2011). The US e-File Initiative: An Investigation of the antecedents to Adoption from the Individual Taxpayers' Perspective. E-Service Journal. 2-19. 
Chaouali, W., Yahia, IB, and Charfeddine, L. (2016). Understanding Citizens' Adoption of E-Filing in Developing Countries: An Empirical Investigation. Journal of High Technology Management Research. 161-176.

Chen, JV, Jubilado, RJ, \& Capistrano, EP. (2015). Factors Affecting Online Tax Filling An Application of the IS Success Model and Trust Theory. Computers in Human Behavior. 251-262.

Christian, CR, \& Alm, J. (2014). Empathy, Sympathy, and Tax Compliance. Journal of Economic Psychology. 62-82.

Eichfelder, S., \& Schorn, M. (2009). Tax compliance costs: A business administration perspective. 1-32.

Victoria, BC, Palil, MR, \& Maelah, R. (2017). Perception on justice, trust and tax compliance behavior in Malaysia. Kasetsart Journal of Social Sciences. 226-232.

Fatih Yllmaz, and Jacqueline Coolidge. (2013). Can E-Filing Tax Compliance Reduce Costs in Developing Countries? The World Bank Investment Climate Department of International Trade and Investment Unit.

Fu, JR, Farn, CK, \& Chao, WP. (2006). Acceptance of Electronic Tax Filling: A Study of Taxpayer Intentions. Information \& Management, 109-126.

Ibrahim, I. (2014). The Compliance Time Costs of Malaysian Personal Income Tax System: E-filers vs. Manual-filers. International Conference on Accounting Studies (pp. 522527). Kuala Lumpur: Elsevier Ltd.

Kotakorpi, K., \& Laamanen, J. (2016). Prelled income tax returns and tax compliance: Evidence from a natural experiment.

Lisi, G. (2014). The Interaction Between Trust and Power: Effects on Tax Compliance and Macroeconomic Implications. Journal of Behavioral and Experimental Economics. 24-33.

Lisi, G. (2015). Tax Morale, Tax Compliance and the Optimal Tax Policy. Economic Analysis and Policy, 27-32.

Mangoting, Y., Sukoharsono, EG, \& Rosidi. (2015). Developing a Model of Tax Compliance Perspective from Social Contract: mitigating the Tax Evasion. 2nd Global Conference on Business and Social Science. Bali: Elsevier Ltd. 966-971

Mendoza, JP, Wielhouwer, JL, \& Kirchler, E. (2017). The Effect of backfiring on Tax Compliance Auditing. Journal of Economic Psychology. 284-294.

Mustapha, B., \& Sheikh Obid, SB (2014). Tax Service Quality: The mediating Effect of Perceived Ease of Use of the Online Tax System. Global Conference on Business and Social Science. Kuala Lumpur: Elsevier Ltd.

Pappadá, F., \& Zylberberg, Y. (2017). Austerity and Tax Compliance. European Economic Review. 506-524.

Pippin, S., \& Tosun, M. (2014). Electronic Tax Filing in the United States: An Analysis of Possible Success factors. Electronic Journal of e-Government Vol. 12. 22-38. 
Santhanamerya, T., \& Ramayah, T. (2012). Continued Usage Intention of E-Filing System in Malaysia: The Role of Optimism Bias. International Congress on Interdisciplinary Business and Social Science. Elsevier Ltd. 397-403

Savitri, E., \& Musfialdy. (2015). The Effect of Taxpayer Awareness, Socialization Tax, Tax Penalties, Compliance Cost at Taxpayer Compliance with Service Quality as mediating variable. 3rd Global Conference on Business and Social Science. Kuala Lumpur: Elsevier Ltd. 682-687

Schaupp, LC, Carter, L., \& Mcbride, ME. (2010). E-File Adoption: A Study of US Taxpayers' Intentions. Computers in Human Behavior. 636-644.

Syed Kashif Raza Zaidi, Cassy Daniels Henderson, and Gaurav Gupta. (2017). The Moderating Effect of Culture on E-Filing Taxes: Evidence from India. Journal of Accounting in Emerging Economies. 134-152.

Warren, N. (2016). E-Filing and Compliance Risk: Evidence From Australian Personal Income Tax deductions. 12th International Conference on Tax Administration. Sydney. 1-21 